\title{
Influence of natural and synthetic carotenoids on the color of egg yolk
}

\author{
Fernanda Papa Spada ${ }^{*}$, Miriam Mabel Selani ${ }^{1}$, Antonio Augusto Domingos Coelho², Vicente José Maria Savino², Arnaldo Antônio
} Rodella ${ }^{3}$, Miriam Coelho Souza ${ }^{4}$, Flavia Salgado Fischer ${ }^{4}$, Dayane Elizabethe Aokui Lemes ${ }^{4}$, Solange Guidolin Canniatti-Brazaca ${ }^{1}$

\author{
${ }^{1}$ University of São Paulo/ESALQ - Dept. of Agri-food industry, \\ Food and Nutrition, Av. Pádua Dias, 11, C.P. 9 -13418-900 \\ - Piracicaba, SP - Brazil. \\ 2University of São Paulo/ESALQ - Dept. of Genetics. \\ UUniversity of São Paulo/ESALQ - Dept. of Math, Chemistry \\ and Statistics. \\ ${ }^{4}$ Methodist University of Piracicaba/Faculty of Health \\ Sciences, Rod. do Açúcar, km 151 -13400-911 - \\ Piracicaba, SP - Brazil. \\ *Corresponding author <fernanda.spada@usp.br>
}

Edited by: Luís Guilherme de Lima Ferreira Guido

Received September 22, 2014

Accepted October 06, 2015

\begin{abstract}
Carotenoids are incorporated into the diet of laying hens in order to modify the yolk color. A natural source of carotenoids in tropical countries is annatto, which could be used in the diets of hens. This study aimed to evaluate the addition of natural (annatto) and synthetic carotenoids to the diet of laying hens (commercial and alternative) and their effects on yolk color and consumer sensory perception of fresh and stored eggs obtained from two different preparations (boiled and fried). Physicochemical analysis of proximate composition, thiobarbituric acid reactive substances (TBARS), emulsion activity and instrumental color were performed. Cooking caused significant alterations to the moisture in the preparations and this may have directly affected the color intensity, influencing factors related to egg appearance. In this study, $85 \%$ of the panelists indicated that yolk color is an important attribute of the product's quality. There was no antioxidant effect of the carotenoids in raw eggs. Synthetic additives should be better dosed to obtain the desired effect. Storage did not alter the proximate composition of the eggs. Keywords: Bixa orellana, prepared foods, sensory evaluation, genetic diversity
\end{abstract}

\section{Introduction}

Annatto stands out as a natural source of carotenoids, and is widely used in the food industry (Scotter, 2009). The addition of synthetic carotenoids such as canthaxanthin and apo-ester to the diet of laying hens is a common practice, applied with the aim of improving yolk color (Sirri et al., 2007; Santos-Bocanegra et al., 2004). However, scientific studies which have evaluated consumer sensory perception of eggs obtained from hens fed with diets supplemented with carotenoids are scarce.

There is a belief that eggs from alternative strains or management (free range) have a distinctive color and quality, resulting in products with higher added value. In Brazil, considering egg intake in its primary form, 87 $\%$ of households prepare boiled eggs and $80 \%$ prepare fried eggs, both with solidified yolks.

Annatto is an effective additive capable of modifying egg yolk color when added to the diet of laying hens (Harder et al., 2007), which is an interesting effect, since yolk color is a differential attribute of sensory appeal (Hammershøj and Steenfeldt, 2012). Some studies that evaluated the use of natural additives in order to modify the lipid and antioxidant composition of yolk reported alterations in the sensory characteristics (Horsted et al., 2010; Sujatha and Narahari, 2010) and the emulsion activity of eggs (Tallarico et al., 2002). However, it is unknown how the addition of annatto in the diet of hens modifies consumer sensory perception of eggs compared to those obtained from diets with synthetic additives, as well as how these additives act in alternative strain hens (free range).

Since the studies available in the literature have evaluated eggs in only one type of cooking, at different periods of posture and have used a trained panel for sensory analysis, this study sought to understand consumer acceptance of both types of eggs, obtained and evaluated in the same laying and storage periods, and prepared using two different cooking methods.

Thus, considering the following: eggs from alternative strains have higher added-value, yolk color is an expressive sensory factor for consumers, Brazil has a significant production of annatto, and the intake of boiled and fried eggs is present in more than $80 \%$ of the Brazilian households, this study aimed to evaluate how natural (annatto) and synthetic carotenoids, added to laying hens' diet (alternative and commercial strains) influence yolk color and consumer sensory perception of eggs prepared using two different cooking methods (boiled and fried).

\section{Materials and Methods}

\section{Hens, management and diet}

Eighty laying hens from Carijó-Barbada alternative strain (CB) (Piracicaba, São Paulo) and 80 laying hens from Isa-Brown commercial strain (IB), both with 33 weeks of laying age, were used in this study.

Before starting the experiment, the hens went through a 15 day environment adaptation period, in individual cages measuring $25 \mathrm{~cm} \times 37 \mathrm{~cm} \times 40 \mathrm{~cm}$ (width, length, height) with a daily supply of water and feed. Due to different nutritional requirements, the strains CB (middleweight $3.0 \mathrm{~kg}$ ) and IB (middleweight $1.8 \mathrm{~kg}$ ) received $160 \mathrm{~g}$ and $120 \mathrm{~g} \mathrm{~d}^{-1}$ of the diet, respectively. The diet was controlled to standardize individual consumption of carotenoids. A completely randomized design, with 8 treatments (2 strains and 4 diets) was constructed. 
This study used a commercial diet for hens from 18 weeks of age, containing $4.5 \%$ limestone; $2.5 \%$ ether extract; $0.6 \%$ phosphorus; $5 \%$ crude fiber; $15 \%$ ash; $16 \%$ crude protein and $12 \%$ moisture. The premix contained: vitamins A (10000 IU), B12 (15.5 $\left.\mu \mathrm{g} \mathrm{kg}^{-1}\right), \mathrm{B} 1(1.5$ $\left.\mathrm{mg} \mathrm{kg}{ }^{-1}\right), \mathrm{B} 2\left(5 \mathrm{mg} \mathrm{kg}^{-1}\right), \mathrm{B} 6\left(2 \mathrm{mg} \mathrm{kg}^{-1}\right), \mathrm{D} 3$ (2000 IU), E $\left(6 \mathrm{mg} \mathrm{kg}^{-1}\right), \mathrm{K} 3\left(2 \mathrm{mg} \mathrm{kg}^{-1}\right)$, folic acid $\left(0.4 \mathrm{mg} \mathrm{kg}^{-1}\right)$, biotin $\left(0.03 \mathrm{mg} \mathrm{kg}^{-1}\right)$, methionine $\left(800 \mathrm{mg} \mathrm{kg}^{-1}\right)$, niacin (15 $\left.\mathrm{mg} \mathrm{kg}{ }^{-1}\right)$, cooper $\left(6 \mathrm{mg} \mathrm{kg}^{-1}\right)$, zinc $\left(60 \mathrm{mg} \mathrm{kg}^{-1}\right)$, iron (50 $\left.\mathrm{mg} \mathrm{kg}^{-1}\right)$, iodine $\left(1.25 \mathrm{mg} \mathrm{kg}^{-1}\right)$, manganese $\left(80 \mathrm{mg} \mathrm{kg}^{-1}\right)$, selenium (0.15 $\left.\mathrm{mg} \mathrm{kg}^{-1}\right)$, sodium (1040 $\left.\mathrm{mg} \mathrm{kg}^{-1}\right)$, calcium pantothenate $\left(10 \mathrm{mg} \mathrm{kg}^{-1}\right)$, as well as an antioxidant (100 $\left.\mathrm{mg} \mathrm{kg}{ }^{-1}\right)$, and growth promoter $\left(10 \mathrm{mg} \mathrm{kg}^{-1}\right)$. The diet was prepared in three separate batches, every 20 days, to avoid problems with lipid oxidation.

The fresh annatto added to the commercial diet was ground, sieved through sieve number 2 (hole size of $0.002 \mathrm{~m}$ diameter), homogenized in a mixer and added to the diets at concentrations of 1.5 and $2.0 \%$ (Harder et al., 2007). Synthetic additives were added at a concentration of $0.001 \%$ of Carophyll yellow (apo-esther) and $0.006 \%$ of Carophyll red (canthaxanthin). The control treatments received corn starch as an inert compound in the commercial diet.

After the adaptive period, at the beginning of the thirty-fifth week of age, the hens were divided into eight treatments, each one applied to 20 laying hens: (CBC) Carijó-Barbada: control; (IBC) Isa Brown: control; (CBA) Carijó-Barbada: $0.001 \%$ Carophyllyellow and $0.006 \%$ Carophyll red; (IBA) Isa Brown: $0.001 \%$ Carophyll yellow and $0.006 \%$ Carophyll red; (CBNI) Carijó-Barbada: $1.5 \%$ annatto; (IBNI) Isa Brown: $1.5 \%$ annatto; (CBNII) Carijó-Barbada: $2 \%$ annatto and (IBNII) Isa Brown: $2 \%$ annatto.

Additives were administered at the beginning of the thirty-fifth week of posture and collection of samples was initiated at the thirty-seventh week, after yolk color stabilization (Harder et al., 2007). The eggs were stored in paper trays, for 36 days, at a controlled temperature of $25^{\circ} \mathrm{C} \pm 0.2$ and relative humidity of $90 \%$. Analyses of proximate composition and thiobarbituric acid reactive substances (TBARS) were performed on fresh eggs and after 36 days of storage, on the instrumental color in fresh eggs, and after 14, 28, and 36 days of storage. Sensory analysis of fresh eggs and after 14 and 28 days of storage was then carried out. Emulsion activity was performed just on fresh eggs.

Boiled eggs were cooked in a stainless steel pan, in the proportion of $1.6 \mathrm{~L}$ of water $\left(\right.$ at $97^{\circ} \mathrm{C}$ ) for 20 eggs, for $10 \mathrm{~min}$. The fried eggs were prepared individually, in anti-adherent frying pans, with $7 \mathrm{~mL}$ of boiling soybean oil. In both preparations the yolk was totally solid.

\section{Analysis of samples}

The acquisition and consumer preference survey, as well as the sensory analysis were approved by the Ethics Committee of Human Research of the University of São Paulo - ESALQ (COET/022/07). Two hundred and forty consumers, aged between 18 and 60 years, were asked about their influence on the purchase decision at home, the characteristics they considered important for egg purchase and their egg intake frequency.

Raw, boiled and fried eggs were freeze-dried and submitted to proximate composition analysis (AOAC, 2006). Two replicates, containing 3 eggs each, were generated.

Lipid oxidation was determined by measuring thiobarbituric acid reactive substances (TBARS), in freeze-dried yolk, following Vyncke's method (1970). Three grams of freeze-dried yolk were added to $15 \mathrm{~mL}$ of a solution of trichloroacetic acid, ethylendiaminetetraacetic, and propyl 3,4,5-trihydroxy benzoate (75: 1: $1)$. The samples were then homogenized in a homogenizer, at $14000 \mathrm{rpm}$ for $30 \mathrm{~s}$. Next, the solution was filtered and an aliquot of the filtrate $(5 \mathrm{~mL})$ was added to $5 \mathrm{~mL}$ of 2-thiobarbituric acid. The samples were incubated in a water bath at $97.5{ }^{\circ} \mathrm{C}$ for one hour and then cooled for $15 \mathrm{~min}$ in cold water (water and ice). Absorbance was measured at $538 \mathrm{~nm}$. For TBARS, two repetitions of the analysis, containing 3 eggs each, were performed.

Instrumental color was measured using a colorimeter, with illuminant D65, previously calibrated on a white surface ( $\mathrm{Y}=93.7, \mathrm{x}=0.3160$ and $\mathrm{y}=0.3323$ ). This measurement was performed on 25 raw eggs for each treatment, with one reading for each yolk.

Forty non-smoker panelists for each session, aged between 18 and 60 years were subjected to sensory analysis procedures. A hedonic scale $(1=$ dislike extremely, 9 = like extremely) was used to evaluate the appearance, odor, flavor and texture of the eggs. The acceptance test was determined using a sensory computer program. Panelists received samples of all treatments in individual cabins and, in different sessions for boiled and fried eggs, so as to avoid panelist fatigue.

Each panelist received one-quarter of the boiled egg and one-sixth of the fried egg, which was served on white plates, coded with three-digit code numbers. Water was offered to the panelists in order to clean the palate between samples. For visual analysis of color and appearance of fried eggs, panelists received simultaneously eight samples (cut in half), allowing for global analysis.

Emulsion activity was determined by electric conductivity of the emulsions, obtained from $200 \mathrm{~mL}$ of yolk solutions (at concentrations of 10,20 and $50 \%(\mathrm{w} / \mathrm{w}$ ) of yolk and distilled water) and $50 \mathrm{~mL}$ of soybean oil at $25{ }^{\circ} \mathrm{C}$. These solutions were homogenized in a blender (18.000 rpm) for $3 \mathrm{~min}$ (Sousa, 2007). The $\mathrm{pH}$ of the yolk suspensions were previously adjusted to 7.5 and the conductivity $\left(\mathrm{mS} \mathrm{cm}^{-1}\right)$ measured using a constant electrode of cell 1 at $25{ }^{\circ} \mathrm{C}$ connected to the equipment. In this analysis, 10 yolks of each treatment were homogenized for subsequent fractionation in nine aliquots of 10,20 and $50 \%$ of the yolk. 


\section{Statistical analysis}

Analysis of variance (ANOVA) was carried out to analyze the results and treatment comparisons were performed by Tukey's test ( $p \leq 0.05)$, using the SAS (Statistical Analysis System, 9.2) software PROC ANOVA and PROC GLM (Tukey).

\section{Results and Discussion}

\section{Proximate composition}

The results of the proximate composition of the same treatments in different preparations showed that all raw egg treatments presented higher moisture content than the fried eggs (Figure 1A and Figure 2A). This occurred because, during frying, large amounts of water are removed, condensing the egg components. However, there was a difference in moisture (Figure 1A) content of raw and boiled fresh eggs in treatments IBC, IBA, and IBNII, which correspond to the IsaBrown treatments. After 36 days of storage, a difference in moisture content of raw and boiled eggs was found in treatment IBNI only, where boiled eggs had higher moisture levels compared to raw eggs (Figure
2A). Obviously, the frying procedure removed more water compared to boiling.

Eggs from the Carijó-Barbada strain presented lower moisture content than eggs from the Isa-Brown strain, after 36 days of storage (Table 1). This can be explained by the high percentage of egg white in eggs from the Isa-Brown strain (Sirri et al., 2007). Comparing these results with the moisture values obtained at the initial point, the same behavior occurred, except for the fried preparation, which did not present any difference in moisture between strains.

Fresh fried eggs did not present significant differences in moisture (Table 1). During the cooking process, microstructural changes occur (gelatinization and protein denaturation) and the main effect of these changes is mass transfer (Rahimi and Ngadi, 2014). However, the rapid water evaporation and crust formation during frying probably equalized the differences in eggs whose structures were preserved.

The highest values of ether extract were observed in fried samples (Figures $1 \mathrm{~B}$ and $2 \mathrm{~B}$ ), whose average content was $55 \%$ higher than those found in raw and boiled eggs, probably due to the addition of oil in the preparation. Ra-
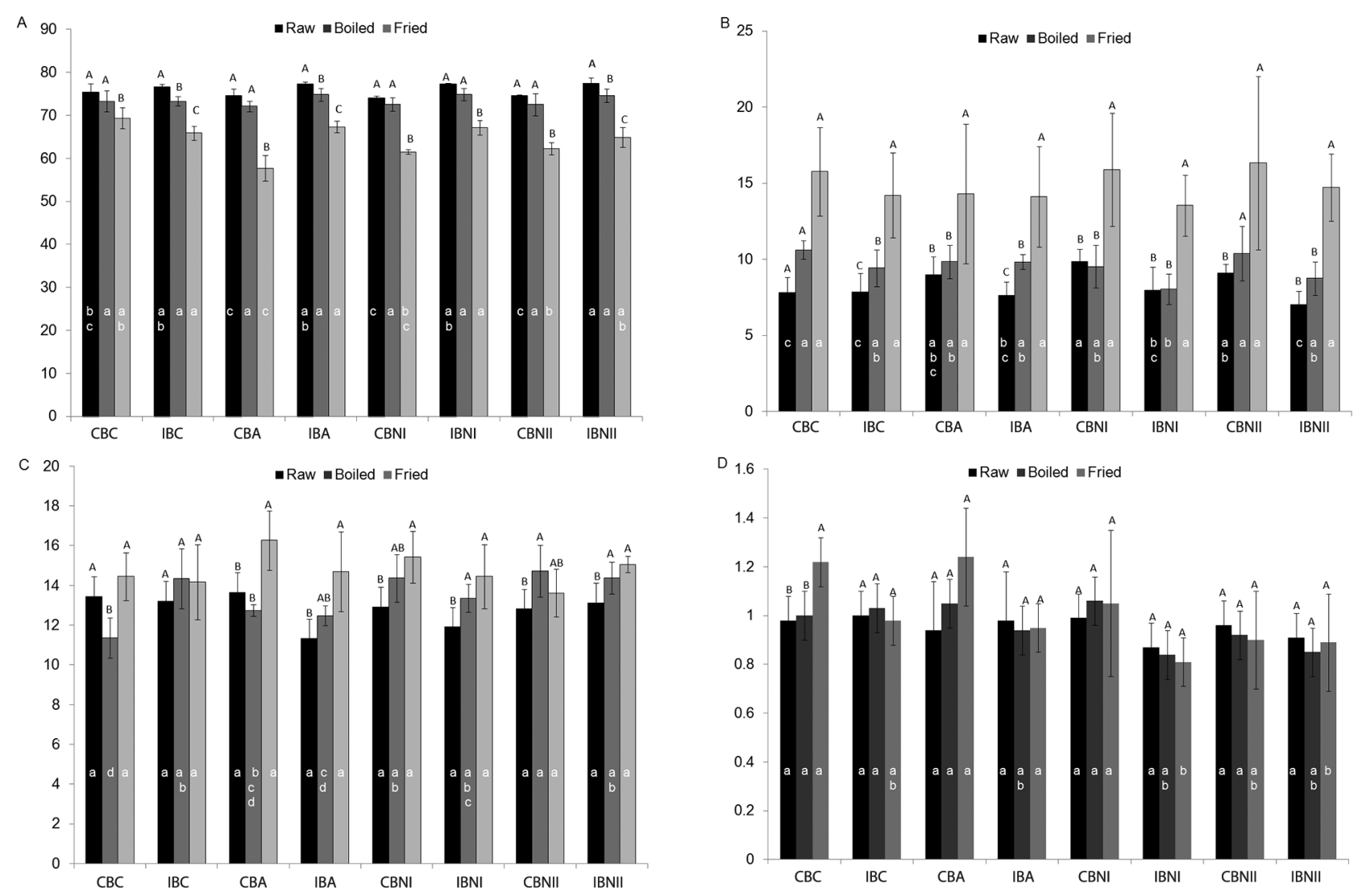

Figure 1- Moisture (A), ether extract (B), protein (C), and ash (D) percentage of raw, boiled and fried fresh eggs. Different lowercase letters in the graphics column compare each preparation and different capital letters compare the same treatments in different preparations $(p \leq 0.05)$ as per the Tukey test. N = 9. CBC - Carijó-Barbada: control; IBC - Isa Brown: control; CBA - Carijó-Barbada: additive; IBA- Isa Brown: additive; CBNI - Carijó-Barbada: 1.5 \% annato; IBNI - Isa Brown: 1.5 \% annato; CBNII - Carijó-Barbada: 2 \% annato and IBNII - Isa Brown: 2 \% annato. 

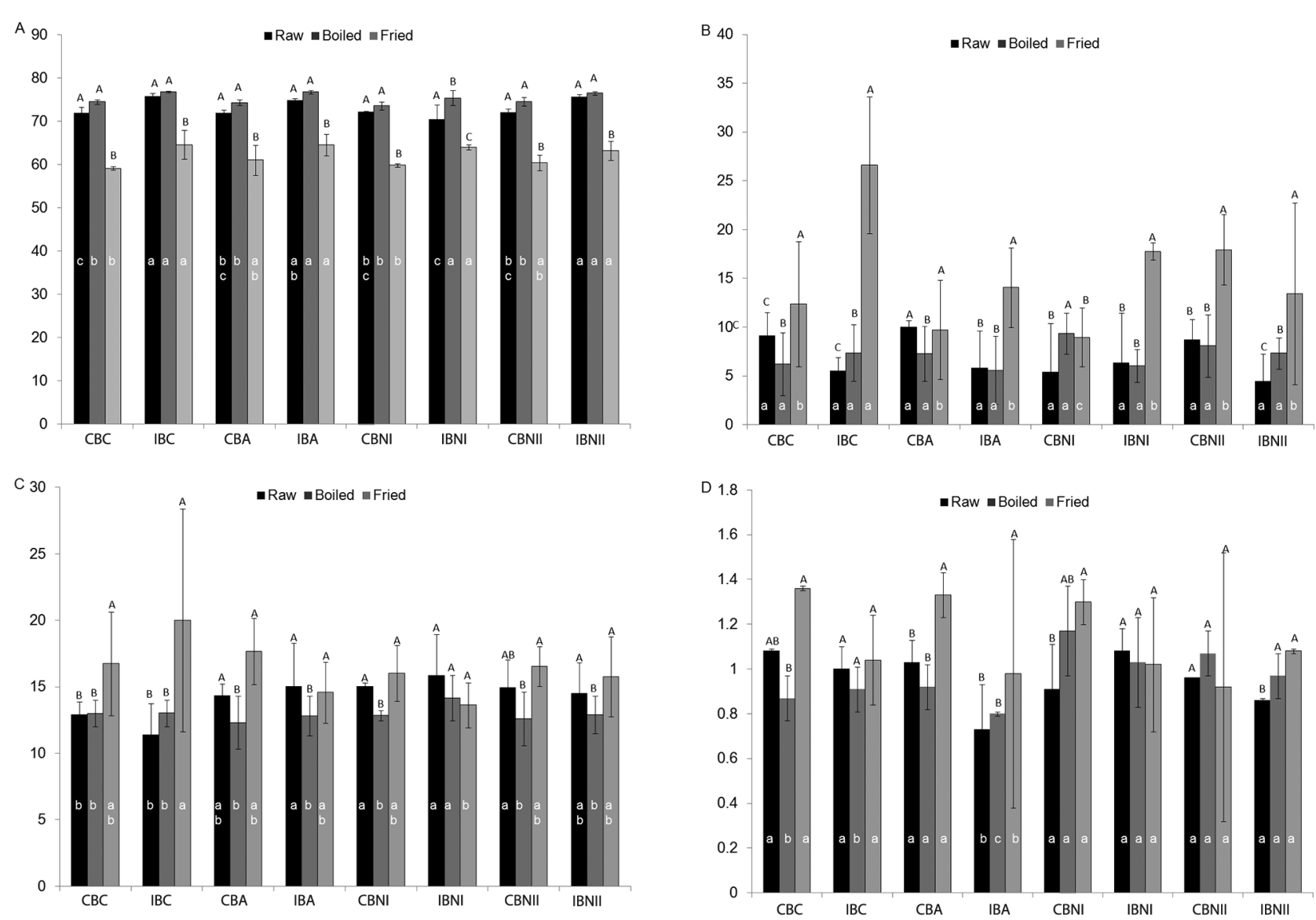

Figure 2 - Moisture (A), ether extract (B), protein (C), and ash (D) percentage of raw, boiled and fried stored eggs. Different lowercase letters in the graphics column compare each preparation and different capital letters compare the same treatments in different preparations ( $p \leq 0.05)$ as per the Tukey test. $\mathrm{N}=9$. CBC - Carijó-Barbada: control; IBC - Isa Brown: control; CBA - Carijó-Barbada: additive; IBA - Isa Brown: additive; CBNI - Carijó-Barbada: 1.5 \% annato; IBNI - Isa Brown: 1.5 \% annato; CBNII - Carijó-Barbada: 2 \% annato and IBNII - Isa Brown: 2 \% annato.

Table 1 - Average \pm standard deviation of moisture, ash, protein, and ether extract percentage of raw, boiled and fried eggs (fresh and stored for 36 days) considering the difference between strains.

\begin{tabular}{|c|c|c|c|c|c|c|c|}
\hline \multirow{2}{*}{\multicolumn{2}{|c|}{$\begin{array}{l}\text { Preparation } \\
\text { Strain }\end{array}$}} & \multicolumn{2}{|c|}{ Raw } & \multicolumn{2}{|c|}{ Boiled } & \multicolumn{2}{|c|}{ Fried } \\
\hline & & Carijó-Barbada & Isa-Brown & Carijó-Barbada & Isa-Brown & Carijó-Barbada & Isa-Brown \\
\hline \multirow{2}{*}{$\begin{array}{l}\text { Fresh } \\
36 \text { days }\end{array}$} & \multirow{2}{*}{ Moisture } & $74.7 \pm 1.3 b$ & $77.1 \pm 0.8 \mathrm{a}$ & $72.6 \pm 1.9 b$ & $74.4 \pm 1.5 \mathrm{a}$ & $61.5 \pm 3.1 \mathrm{a}$ & $66.3 \pm 1.9 \mathrm{a}$ \\
\hline & & $72.1 \pm 0.7 b$ & $74.6 \pm 2.4 \mathrm{a}$ & $74.4 \pm 0.8 b$ & $76.3 \pm 1.1 \mathrm{a}$ & $60.1 \pm 2.0 \mathrm{~b}$ & $64.0 \pm 1.9 \mathrm{a}$ \\
\hline \multirow{2}{*}{$\begin{array}{l}\text { Fresh } \\
36 \text { days }\end{array}$} & \multirow{2}{*}{ Ether Extract } & $8.9 \pm 1.1 \mathrm{a}$ & $7.6 \pm 1.2 \mathrm{~b}$ & $9.1 \pm 0.3 \mathrm{a}$ & $8.0 \pm 0.2 b$ & $15.6 \pm 4.1 \mathrm{a}$ & $14.1 \pm 2.5 \mathrm{a}$ \\
\hline & & $8.4 \pm 3.0 \mathrm{a}$ & $5.4 \pm 3.1 b$ & $7.4 \pm 1.0 \mathrm{a}$ & $6.0 \pm 1.3 b$ & $12.2 \pm 6.4 \mathrm{a}$ & $15.2 \pm 4.8 \mathrm{a}$ \\
\hline \multirow{2}{*}{$\begin{array}{l}\text { Fresh } \\
36 \text { days }\end{array}$} & \multirow{2}{*}{ Protein } & $12.4 \pm 1.1 \mathrm{a}$ & $12.9 \pm 1.7 \mathrm{a}$ & $13.3 \pm 1.7 \mathrm{a}$ & $13.6 \pm 1.2 \mathrm{a}$ & $14.9 \pm 1.6 \mathrm{a}$ & $14.6 \pm 1.5 \mathrm{a}$ \\
\hline & & $143 \pm 1.4 \mathrm{a}$ & $14.0 \pm 3.1 \mathrm{a}$ & $12.7 \pm 1.5 \mathrm{a}$ & $13.3 \pm 1.5 \mathrm{a}$ & $16.7 \pm 2.5 \mathrm{a}$ & $14.3 \pm 2.1 \mathrm{a}$ \\
\hline \multirow{2}{*}{$\begin{array}{l}\text { Fresh } \\
36 \text { days }\end{array}$} & \multirow{2}{*}{ Ash } & $0.9 \pm 0.1 \mathrm{a}$ & $0.9 \pm 0.1 \mathrm{a}$ & $1.0 \pm 0.1 \mathrm{a}$ & $0.9 \pm 0.1 b$ & $1.1 \pm 0.2 \mathrm{a}$ & $0.9 \pm 0.1 b$ \\
\hline & & $1.0 \pm 0.1 \mathrm{a}$ & $0.9 \pm 0.2 \mathrm{a}$ & $0.9 \pm 0.1 \mathrm{a}$ & $0.8 \pm 0.1 b$ & $1.2 \pm 0.3 \mathrm{a}$ & $0.8 \pm 0.5 \mathrm{a}$ \\
\hline
\end{tabular}

Averages followed by different letters in the same line and the same storaged time differ significantly $(p \leq 0.05)$ as per the Tukey test. $N=9$.

himi and Ngadi (2014) reported that after frying and during the cooling phase, water vapor condensation and subsequently oil pressure decrease. Due to this, oil adhered to the surface of the product is sucked into large voids and crevices due to the generating of a vacuum effect.

As expected, regardless of the treatment, fried eggs presented the highest ether extract content and, between them, there was no significant difference $(p$ $\geq 0.05$ ) (Figure $1 \mathrm{~B}$ and Figure 2B). For the ether extract, there was no difference between the fried egg strains (Table 1). However, in raw and boiled preparations, it was verified that, in both storage times, eggs from Carijó-Barbada presented the highest fat content. These results are different to those determined 
by Anderson (2013), because they found higher total fat content in white eggs, when they compared nutritional composition and the component percentages of four egg strains.

There were no changes in protein content between the strains and during the storage time (Table 1). However, variations between preparations were observed (Figure $1 \mathrm{C}$ and Figure $2 \mathrm{C}$ ), which are probably related to moisture amount.

There was no difference in the ash content of fresh eggs (Figure 1D) between preparations, except for the control $(\mathrm{CBC})$. Storage caused variations in the amount
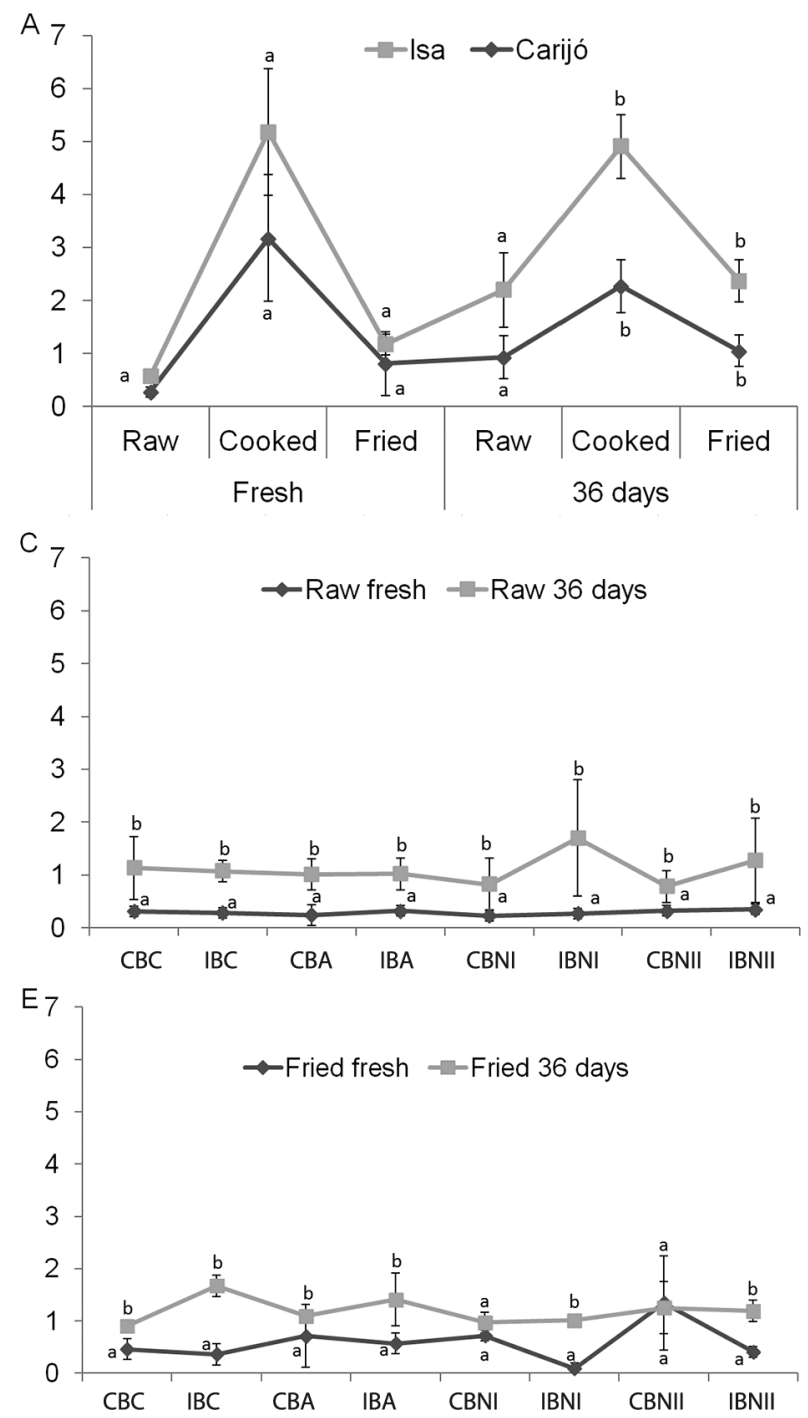

of ash (Figure 2D), but these changes are not related to the variables studied.

Ash contents differed $(p \leq 0.05)$ in the boiled preparation after 36 days of storage, with the highest values being found in eggs from the Carijó-Barbada strain. This behavior was also observed at the beginning of the boiled and fried eggs preparations.

\section{Lipid oxidation}

The results of the lipid oxidation are presented in Figure 3. There was no effect $(p \geq 0.05)$ of strains on lipid oxidation of raw eggs, but both boiled and fried
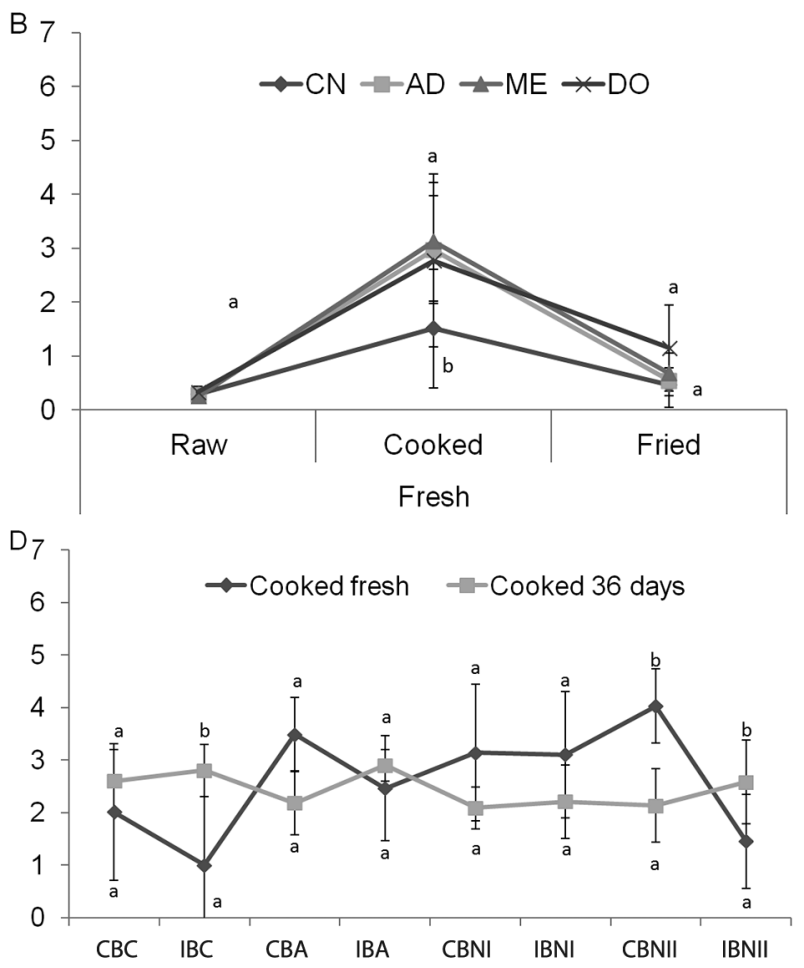

Figure 3 - A-Comparison of TBARS values of fresh and stored eggs of the two strains and three cooking methods studied; B - Comparison of TBARS values of fresh eggs obtained from different diets; C- Comparison of TBARS values of fresh and stored raw eggs; D - Comparison of TBARS values of fresh and stored fried eggs; $\mathrm{E}$ - Comparison of TBARS values of fresh and stored boiled eggs. CBC - Carijó-Barbada: control; IBC - Isa-Brown: control; CBA - Carijó-Barbada: additive; IBA - Isa Brown: additive; CBNI - Carijó-Barbada: 1.5 \% of annatto; IBNI - Isa Brow: $1.5 \%$ of annatto; CBNII - Carijó-Barbada: $2 \%$ of annatto and IBNII- Isa-Brown: $2 \%$ of annatto. Carijó = Carijó-Barbada; Isa = Isa-Brown. CN = natural dye; $A D=$ Additive; $M E=1.5 \%$ of annatto; $D O=2 \%$ of annatto. $N=4$. Averages followed by different lowercase letters in the same treatments are significantly different $(p \leq 0.05)$ as per the Tukey test. 
eggs had higher lipid oxidation after storage (Figure 3A). Fresh eggs with $2 \%$ of annatto (IBNII) exhibited low lipid oxidation (Figure 3B), even after cooking (Figure $3 \mathrm{D}$ and $3 \mathrm{E}$ ). Several carotenoids including astaxanthin, canthaxanthin and zeaxanthin did show an anti-oxidant effect, especially in the presence of peroxide radicals, being dependent on carotenoid concentration (Edge et al., 1997).

For most of the results, lipid oxidation was higher in eggs stored for 36 days compared to fresh eggs, probably due to the storage time and dehydration.

Boiled eggs showed higher oxidation than fried eggs, probably due to the length of contact with the heat source, since boiled eggs were cooked for $10 \mathrm{~min}$ in water at $97{ }^{\circ} \mathrm{C}$ and fried eggs remained for less time at higher temperatures (Figures 3C, 3D and 3E).

\section{Color analysis}

The objective analysis of colorallows to evaluate the relationship between the changes caused by the carotenoids and the consumer acceptance. Furthermore, this measurement can demonstrate the effectiveness of carotenoid incorporation in the redness and yellowness of the product.

In general, differences in the $\mathrm{L}^{*}$ parameter were verified between treatments with carotenoids and control treatments, since treatments $\mathrm{CBC}$ and IBC were lighter compared to other treatments, for all storage times evaluated (Table 2). Treatments with carotenoids had the highest intensities of red color and the lowest intensities of yellow color. It was possible to verify that the treatment with annatto at $1.5 \%$ presented a difference in red color intensity compared to the treatment with annatto at $2 \%$. This phenomenon was also observed in the experiments of Silva et al., (2000) and Galobart et al., (2004). The highest $a^{*}$ values were verified in treatments with synthetic additives. Based on the instrumental color results, annatto presented a desirable effect, which was also verified by the results of sensory evaluation. Harder et al., (2007) reported the presence of stains concentrating the dyes at certain points of the yolk, and due to this, the carotenoids would act as time markers. However, in the present experiment, the presence of egg stains was not observed.

Isa Brown treatments showed the highest lightness after 14 storage days and redness after 28 days (Figure 4). For yellowness, after 14 and 36 days of storage, Isa Brown treatments showed higher values in comparison to Carijó-Barbada. Sirri et al., (2007) studied commercial hens strain (white Hy-line and Isa Brown), and concluded that the Isa Brown strain presented the highest capacity for transfering carotenoids to the yolk. In the present study, Carijó-Barbada showed a more intense yolk staining, but storage time could have been responsible for promoting color differences in yolk, as well.

Nevertheless, other factors in the experiment should be taken into account before formulating a conclusion. Carijó-Barbada hens have higher nutritional requirements, which lead to a higher diet intake (although controlled). Anderson (2013) studied four strains of hen (Hy-Line Brown, Hy-Line w-36, Bovans Brown and Bovans White) and found different colors for the different strains.

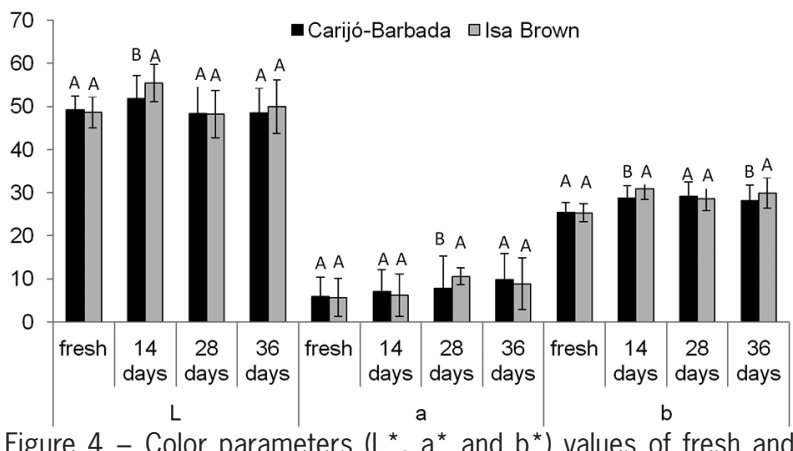

Figure 4 - Color parameters $\left(L^{*}, a^{*}\right.$ and $\left.b^{*}\right)$ values of fresh and stored $(14,28$, and 36 days) raw egg yolks, in different strains. Averages during the storage time of the same strain differ significantly $(p \leq 0.05)$ as per the Tukey test. $\mathrm{N}=25$.

Table 2 - Average \pm standard deviation of $\mathrm{L}^{*}, \mathrm{a}^{*}$ and $\mathrm{b}^{*}$ values of fresh and stored $(14,28$, and 36 days) raw egg yolks, in different treatments.

\begin{tabular}{|c|c|c|c|c|c|c|c|c|c|c|c|c|}
\hline & \multicolumn{4}{|c|}{$\mathrm{L}^{*}$} & \multicolumn{4}{|c|}{$a^{*}$} & \multicolumn{4}{|c|}{$b^{*}$} \\
\hline & Fresh & 14 & 28 & 36 & Fresh & 14 & 28 & 36 & Fresh & 14 & 28 & 36 \\
\hline & & 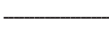 & — days - & 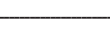 & & 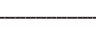 & — days - & 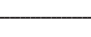 & & 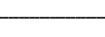 & - days - & 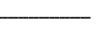 \\
\hline $\mathrm{CBC}$ & $52.5 \mathrm{a}$ & $56.3 a b$ & $51.7 \mathrm{ab}$ & $53.6 \mathrm{ab}$ & $-1.3 \mathrm{e}$ & $-0.7 \mathrm{e}$ & $0.4 \mathrm{~d}$ & $0.6 \mathrm{e}$ & $27.4 \mathrm{a}$ & $31.6 \mathrm{ab}$ & $30.7 \mathrm{ab}$ & $31.4 \mathrm{ab}$ \\
\hline IBC & $52.3 \mathrm{a}$ & $58.0 \mathrm{a}$ & $52.8 \mathrm{a}$ & $55.4 \mathrm{a}$ & $-1.4 \mathrm{e}$ & $-1.3 \mathrm{e}$ & $0.03 \mathrm{~d}$ & $0.2 \mathrm{e}$ & $27.3 \mathrm{a}$ & $32.6 \mathrm{a}$ & $31.4 \mathrm{a}$ & $33.3 \mathrm{a}$ \\
\hline CBA & $47.8 b$ & $49.2 \mathrm{~d}$ & $44.1 \mathrm{C}$ & $45.5 \mathrm{c}$ & $10.3 \mathrm{a}$ & $12.6 \mathrm{a}$ & $15.7 \mathrm{a}$ & $15.9 \mathrm{a}$ & 24.1 bc & $26.8 \mathrm{e}$ & $26.8 \mathrm{c}$ & $26.6 \mathrm{~d}$ \\
\hline IBA & $46.4 b$ & 53.4 bc & $44.9 \mathrm{c}$ & $46.5 \mathrm{c}$ & $9.2 a b$ & $11.0 \mathrm{~b}$ & $14.3 \mathrm{a}$ & $14.8 \mathrm{a}$ & $23.4 \mathrm{c}$ & $29.0 \mathrm{~cd}$ & $27.3 \mathrm{c}$ & $27.5 \mathrm{~d}$ \\
\hline IBNI & $48.1 \mathrm{~b}$ & $56.0 \mathrm{ab}$ & $48.4 a b c$ & 50.0 bc & $6.0 \mathrm{~d}$ & $6.0 \mathrm{~d}$ & $9.5 \mathrm{c}$ & $7.9 \mathrm{~d}$ & $25.3 b$ & $31.4 \mathrm{ab}$ & 28.4 bc & 30.2 bc \\
\hline CBNII & $47.9 \mathrm{~b}$ & $50.9 \mathrm{~cd}$ & 47.8 bc & $45.9 \mathrm{c}$ & $7.9 c$ & $9.3 \mathrm{c}$ & $11.2 \mathrm{~b}$ & $12.5 b$ & $25.2 b$ & $28.2 \mathrm{de}$ & $27.9 \mathrm{c}$ & $26.8 d$ \\
\hline IBNII & $47.5 b$ & $54.0 \mathrm{cb}$ & 47.8 bc & $47.9 \mathrm{c}$ & $8.3 b c$ & $9.0 \mathrm{c}$ & $11.2 \mathrm{~b}$ & $12.2 \mathrm{~b}$ & $25.1 \mathrm{~b}$ & 30.4 bc & 28.4 bc & $28.7 \mathrm{~cd}$ \\
\hline $\mathrm{CV}$ & 0.1 & 0.1 & 0.1 & 0.1 & 0.2 & 0.2 & 0.2 & 0.2 & 0.1 & 0.1 & 0.1 & 0.1 \\
\hline
\end{tabular}




\section{Sensory analysis}

\section{Sensorial panel}

With regard to sensory evaluation, in the sessions where fresh and stored boiled eggs (14 and 28 days) were presented, $70 \%$ and $92 \%$ of the panelists, respectively, were aged between 18 and 28 years. In all fried egg sessions, $90 \%$ of the consumers were aged between 18 and 28 years. The rest of the panelists were older than 29 years.

For the acquisition and consumers' preference survey, $82 \%$ of the panelists answered that they make the purchase decision at home, expressing that the present test fairly represents consumers who buy eggs. With regard to frequency of egg intake, out of the 240 consumers in the test, $34 \%$ answered that they eat eggs monthly, $47 \%$ once a week, $11 \%$ twice a week and $1 \%$ daily.

\section{Sensory characteristics of the eggs}

When panelists were asked about the characteristics that they consider important in the quality of eggs, $85 \%$ mentioned yolk color. Since the panelists cited more than one characteristic, the others mentioned were: size, yolk color, and shell color (40\% of the panelists), yolk and shell color (16\% of the panelists), size and yolk color (16\% of the panelists), yolk color (13\% of the panelists), size and shell color (8\% of the panelists), just shell color ( $3 \%$ of the panelists) and weight and size 14 $\%$ of the consumers).

Without prior knowledge of the differences between treatments, 40 panelists were asked about what samples they would use in their food preparations. The eggs were presented to the panelists in their raw form, on white plates. The results showed that $34 \%$ of the consumers would use eggs from the control treatment (CBC and IBC), while $66 \%$ would use eggs with carotenoids added to the hens' diet, of which $37 \%$ corresponded to eggs from hens fed with annatto.

\section{Acceptance test}

For the appearance attribute of fresh boiled eggs (Table 3), all treatments with carotenoids were different compared to the $\mathrm{CBC}$ and IBC treatments, indicating that the addition of carotenoids improved the appearance of the product. This result is in agreement with Hammershøj and Steenfeldt (2012), and Sujatha and Narahari (2010), which developed new egg products by just changing the diet of hens.

During storage time there was no significant difference in attribute appearance. The results in Table 2 shows that the *a value increased during storage, treatments CBCand IBC have an increased $a^{*}$ after storage. When we compared analytical sensory and color results (Table 3) we observed that the sensory panel was able to evaluate the differences in $\mathrm{L}^{*}$ intensity after storage.

For fried eggs (Table 4), control treatments had better sensory evaluation, and thus, the orange color of the yolk with carotenoids reduced consumers' sensory acceptance (appearance and color). In this preparation, there was a reduction in moisture content (Figure 1A and 2A) which promoted pigment concentration, and enhanced yolk color (Figure 4). It is important to note that treatment CBA had the lowest average for appearance, as shown in Table 4, which suggests that an excess of orange color negatively affects the product.

For the color attribute of fresh boiled eggs, the controls differed $(p \leq 0.05)$ from the treatments with added carotenoids which presented the highest scores (Table 3). This was also the result when storage time was considered, demonstrating that storage did not affect the color of the eggs. For the color of fried eggs (Table 4), the results showed that fresh eggs from treatments CBA, IBA and CBNII differed ( $p \leq 0.05)$ from treatments CBC and IBC. After 14 days of storage, the differences between treatments were reduced.

There was no difference in the odor of boiled eggs in the periods evaluated (Table 3). Apparently, the addition of carotenoids and the different strains tested did not alter the odor of the product. These results are different to those found by Rizzi and Maragon (2012), who compared eggs obtained from different genotypes of hens reared by the organic method, and found that egg profiles showed differences in both odor and flavor.

Table 3 - Average values of sensory scores (appearance, color, texture and flavor attributes) of boiled eggs (Fresh and stored for 14 and 28 days).

\begin{tabular}{|c|c|c|c|c|c|c|c|c|c|c|c|c|c|c|c|}
\hline & \multicolumn{3}{|c|}{ Appearance } & \multicolumn{3}{|c|}{ Odor } & \multicolumn{3}{|c|}{ Color } & \multicolumn{3}{|c|}{ Texture } & \multicolumn{3}{|c|}{ Flavor } \\
\hline & Fresh & 14 & 28 & Fresh & 14 & 28 & Fresh & 14 & 28 & Fresh & 14 & 28 & Fresh & 14 & 28 \\
\hline $\mathrm{CBC}$ & $4.8 \mathrm{c}$ & $5.5 a$ & $5.2 \mathrm{a}$ & $5.7 a$ & $5.4 \mathrm{a}$ & $5.7 \mathrm{a}$ & $4.3 b$ & $5.3 a b$ & $5.0 \mathrm{~b}$ & $5.4 \mathrm{c}$ & $5.9 a$ & $6.6 a$ & $5.9 \mathrm{a}$ & $5.9 a$ & $6.2 \mathrm{a}$ \\
\hline IBC & $4.8 \mathrm{c}$ & $5.3 \mathrm{a}$ & $5.2 \mathrm{a}$ & $5.2 \mathrm{a}$ & $5.4 \mathrm{a}$ & $5.9 \mathrm{a}$ & $4.2 \mathrm{~b}$ & $5.0 \mathrm{~b}$ & $5.0 \mathrm{~b}$ & $5.6 \mathrm{bc}$ & $5.7 \mathrm{a}$ & $6.6 \mathrm{a}$ & $5.4 \mathrm{a}$ & $6.5 \mathrm{a}$ & $6.4 \mathrm{a}$ \\
\hline CBA & $6.5 a b$ & $5.8 \mathrm{a}$ & $5.8 \mathrm{a}$ & $5.8 \mathrm{a}$ & $5.7 \mathrm{a}$ & $5.8 \mathrm{a}$ & $6.5 a$ & $5.8 a b$ & $6.1 \mathrm{ab}$ & $6.4 a b$ & $6.1 \mathrm{a}$ & $6.9 a$ & $6.3 \mathrm{a}$ & $6.7 \mathrm{a}$ & $6.6 \mathrm{a}$ \\
\hline IBA & $6.3 a b$ & $6.1 \mathrm{a}$ & $5.9 a$ & $5.4 \mathrm{a}$ & $5.3 a$ & $5.0 \mathrm{a}$ & $6.2 \mathrm{a}$ & $6.2 \mathrm{a}$ & $6.2 \mathrm{a}$ & $6.4 a b$ & $6.0 \mathrm{a}$ & $6.2 \mathrm{a}$ & $6.3 \mathrm{a}$ & $6.2 \mathrm{a}$ & $6.2 \mathrm{a}$ \\
\hline CBNI & $6.3 a b$ & $5.9 a$ & $6.2 \mathrm{a}$ & $5.8 \mathrm{a}$ & $5.8 a$ & $6.0 \mathrm{a}$ & $6.6 a$ & $6.2 \mathrm{a}$ & $6.8 \mathrm{a}$ & $6.6 a$ & $5.9 \mathrm{a}$ & $6.5 a$ & $6.4 \mathrm{a}$ & $6.1 \mathrm{a}$ & $6.6 \mathrm{a}$ \\
\hline IBNI & $6.3 a b$ & $6.3 a$ & $6.1 \mathrm{a}$ & $5.6 a$ & $6.1 \mathrm{a}$ & $5.9 a$ & $6.3 a$ & $6.3 a$ & $6.4 \mathrm{a}$ & $6.4 a b$ & $6.1 \mathrm{a}$ & $6.6 a$ & $5.8 \mathrm{a}$ & $6.2 \mathrm{a}$ & $6.5 \mathrm{a}$ \\
\hline CBNII & $6.7 a$ & $6.0 \mathrm{a}$ & $5.9 a$ & $5.5 a$ & $5.5 a$ & $6.1 \mathrm{a}$ & $6.5 a$ & $5.9 a b$ & $6.2 \mathrm{a}$ & $6.3 \mathrm{ab}$ & $6.0 \mathrm{a}$ & $6.3 a$ & $6.3 \mathrm{a}$ & $6.2 \mathrm{a}$ & $6.8 \mathrm{a}$ \\
\hline IBNIII & $5.7 \mathrm{bc}$ & $5.9 \mathrm{a}$ & $5.9 \mathrm{a}$ & $5.6 \mathrm{a}$ & $5.8 \mathrm{a}$ & $5.8 \mathrm{a}$ & $6.2 \mathrm{a}$ & $6.2 \mathrm{a}$ & $6.2 \mathrm{a}$ & $5.6 b c$ & $6.2 \mathrm{a}$ & $6.4 \mathrm{a}$ & $5.9 \mathrm{a}$ & $6.3 \mathrm{a}$ & $6.7 \mathrm{a}$ \\
\hline
\end{tabular}


Table 4 - Average values of sensory scores (appearance, color, texture and flavor attributes) of fried eggs (Fresh and stored for 14 and 28 days).

\begin{tabular}{|c|c|c|c|c|c|c|c|c|c|c|c|c|c|c|c|}
\hline & \multicolumn{3}{|c|}{ Appearance } & \multicolumn{3}{|c|}{ Odor } & \multicolumn{3}{|c|}{ Color } & \multicolumn{3}{|c|}{ Texture } & \multicolumn{3}{|c|}{ Flavor } \\
\hline & Fresh & 14 & 28 & Fresh & 14 & 28 & Fresh & 14 & 28 & Fresh & 14 & 28 & Fresh & 14 & 28 \\
\hline $\mathrm{CBC}$ & $6.1 \mathrm{a}$ & $6.5 a$ & $6.4 \mathrm{a}$ & $6.3 \mathrm{a}$ & $6.1 \mathrm{a}$ & $5.7 \mathrm{a}$ & $6.4 \mathrm{a}$ & $6.4 \mathrm{a}$ & $6.1 \mathrm{ab}$ & $5.7 \mathrm{a}$ & $6.1 \mathrm{ab}$ & $6.0 \mathrm{a}$ & $6.0 \mathrm{a}$ & $6.3 \mathrm{a}$ & $6.5 \mathrm{a}$ \\
\hline IBC & $6.2 \mathrm{a}$ & $6.1 \mathrm{ab}$ & $6.5 \mathrm{a}$ & $6.4 \mathrm{a}$ & $6.0 \mathrm{a}$ & $6.2 \mathrm{a}$ & $6.4 \mathrm{a}$ & $6.4 \mathrm{a}$ & $5.9 a b$ & $6.2 \mathrm{a}$ & $6.4 a b$ & $5.9 a$ & $6.3 \mathrm{a}$ & $6.4 \mathrm{a}$ & $6.4 \mathrm{a}$ \\
\hline CBA & $4.0 \mathrm{c}$ & $3.4 \mathrm{c}$ & $4.4 \mathrm{c}$ & $6.2 \mathrm{a}$ & $4.9 \mathrm{~b}$ & $5.7 \mathrm{a}$ & $4.5 \mathrm{c}$ & $3.4 \mathrm{c}$ & $4.6 \mathrm{c}$ & $5.7 \mathrm{a}$ & $5.5 b$ & $6.0 \mathrm{a}$ & $6.3 \mathrm{a}$ & $6.2 \mathrm{a}$ & $6.4 \mathrm{a}$ \\
\hline IBA & $5.2 \mathrm{ab}$ & $5.3 b$ & $6.3 \mathrm{a}$ & $6.0 \mathrm{a}$ & $5.9 a$ & $5.7 \mathrm{a}$ & $5.3 b c$ & $4.8 b$ & $6.1 \mathrm{ab}$ & $6.2 \mathrm{a}$ & $6.5 a b$ & $6.2 \mathrm{a}$ & $6.6 \mathrm{a}$ & $6.1 \mathrm{a}$ & $6.4 \mathrm{a}$ \\
\hline CBNI & $5.9 \mathrm{ab}$ & $6.1 \mathrm{ab}$ & $6.2 \mathrm{ab}$ & $6.3 \mathrm{a}$ & $6.2 \mathrm{a}$ & $5.7 \mathrm{a}$ & $5.8 \mathrm{ab}$ & $6.6 a$ & $6.3 \mathrm{a}$ & $5.7 \mathrm{a}$ & $6.5 \mathrm{ab}$ & $6.0 \mathrm{a}$ & $6.5 \mathrm{a}$ & $6.3 \mathrm{a}$ & $5.9 \mathrm{a}$ \\
\hline IBN| & $5.7 \mathrm{ab}$ & $6.4 \mathrm{a}$ & $6.4 \mathrm{a}$ & $5.8 \mathrm{a}$ & $6.0 \mathrm{a}$ & $6.0 \mathrm{a}$ & $5.6 \mathrm{abc}$ & $6.7 \mathrm{a}$ & $6.3 \mathrm{a}$ & $5.7 \mathrm{a}$ & $6.4 a b$ & $5.9 \mathrm{a}$ & $6.2 \mathrm{a}$ & $6.6 \mathrm{a}$ & $6.1 \mathrm{a}$ \\
\hline CBNII & $4.8 \mathrm{bc}$ & $5.8 a b$ & $4.9 \mathrm{c}$ & $6.2 \mathrm{a}$ & $5.7 \mathrm{ab}$ & $6.1 \mathrm{a}$ & $5.0 \mathrm{bc}$ & $5.7 a b$ & $5.2 \mathrm{bc}$ & $6.1 \mathrm{a}$ & $6.6 \mathrm{a}$ & $5.8 \mathrm{a}$ & $6.3 \mathrm{a}$ & $6.7 \mathrm{a}$ & $5.9 \mathrm{a}$ \\
\hline IBNII & $5.8 \mathrm{ab}$ & $6.4 \mathrm{ab}$ & $5.1 \mathrm{c}$ & $6.2 \mathrm{a}$ & $6.0 \mathrm{a}$ & $5.8 \mathrm{a}$ & $5.6 \mathrm{abc}$ & $6.2 \mathrm{a}$ & $5.2 \mathrm{bc}$ & $6.2 \mathrm{a}$ & $5.9 \mathrm{ab}$ & $6.3 \mathrm{a}$ & $6.5 \mathrm{a}$ & $6.6 \mathrm{a}$ & $6.2 \mathrm{a}$ \\
\hline
\end{tabular}

CBC - Carijó-Barbada: control; IBC- Isa Brown: control; CBA - Carijó-Barbada: additive; IBA - Isa Brown: additive; CBNI - Carijó-Barbada: $1.5 \%$ of annatto; IBNI - Isa Brown: $1.5 \%$ of annatto; CBNII - Carijó-Barbada: $2 \%$ of annatto and IBNII - Isa Brown: $2 \%$ of annatto. Averages followed by different letters differ significantly $(p \leq 0.05)$ in the same column as per the Tukey test. $N=40$.

There was no significant difference $(p \geq 0.05)$ in the texture of boiled eggs after 14 and 28 days of storage. In fresh boiled eggs, treatment CBNI was different from CBC, IBC and IBNII (Table 3). In fried eggs (Table $4)$, differences $(p \leq 0.05)$ appeared only after 14 days of storage, and the only difference was between treatments CBA and CBNII, since both had higher carotenoid concentration.

The attribute flavor did not present significant differences $(p \geq 0.05)$ in any of the periods, for both preparations. Thus, carotenoids added to the diet of the hens, as well as the different strains evaluated, did not alter the flavor of fresh and stored eggs (Table 3 and Table 4). These results corroborate the study by Tallarico (2002) and Sujatha and Narahari (2010) and disagree with those found by Horsted et al., (2010) e Hammershøj and Steenfeldt (2012), who verified that eggs under organic management were tastier.

\section{Emulsion activity}

An objective analysis of emulsion activity was performed in order to know if the addition of carotenoids in the diet of hens could modify the properties of products made with naturally colored yolk. However, according to the results, there was no significant difference $(p \geq$ 0.05) (Figure 5) between the samples with the same yolk concentration $(10,20$ and $50 \%)$ in all treatments.

Thus, the addition of both synthetic and natural carotenoids did not alter the capacity of the eggs to produce emulsions and both strains acted similarly in terms of emulsion activity. These results again corroborate the study of Tallarico (2002), who verified that the addition of oils in hens' diets did not change the emulsion activity. The results of the present study are higher than those obtained by Sousa (2007), especially at a yolk concentration of $50 \%$, demonstrating higher efficiency in emulsion activity. In the study, Sousa (2007) did not report the strains and conditions of the eggs.

With the results obtained in this work we suggest further studies be conducted with the aim of verifying noticeable differences in the same products but masking the color.

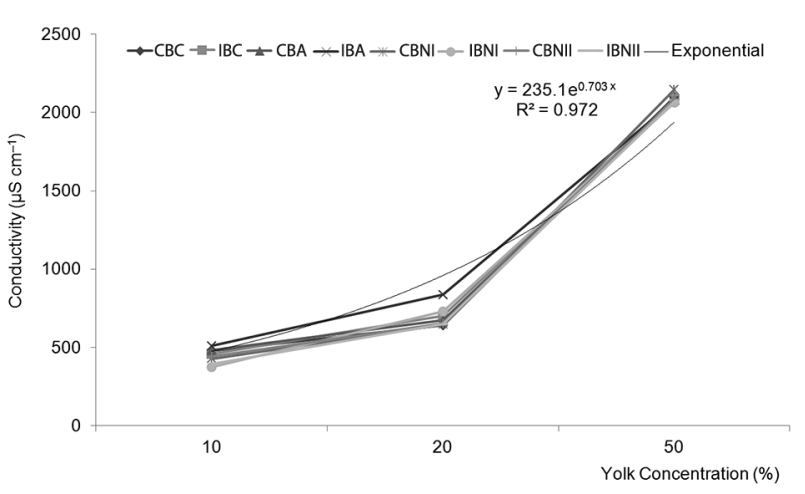

Figure 5 - Conductivity ( $\mu \mathrm{S} \mathrm{cm}^{-1}$ ) of the samples with 10, 20 and $50 \%$ of yolk concentration. CBC - Carijó-Barbada: control; IBC Isa Brow: control; CBA - Carijó-Barbada: additive; IBA - Isa Brown: additive; CBNI - Carijó-Barbada: $1.5 \%$ of annatto; IBNI- Isa Brown: $1.5 \%$ of annatto; CBNII - Carijó-Barbada: $2 \%$ of annatto and IBNII - Isa Brown: $2 \%$ of annatto. $N=3$.

Since the present study showed that yolk color is a determining factor when purchasing the product and as it is hidden from view at the time of purchase, the use of an indicative figure of egg yolk color on the box would be a method of putting the results of this study into practice.

\section{Conclusions}

Annatto acts as a dye on the yolk, which promotes higher acceptance by consumers. Its use did not alter the odor and flavor attributes of the eggs, even after storage. There are indications of texture alterations of the preparations; however, natural dyes can be used as ingredients in eggs, since this addition does not alter emulsion activity. The synthetic additive should be better dosed to obtain the desirable effect, since the red intensity in fried eggs met with rejection by the panelists. Storage time did not alter the proximate composition of the eggs. 


\section{References}

Anderson, K.E. 2013. Comparison of fatty acid, cholesterol, vitamin $\mathrm{A}$ and $\mathrm{E}$ composition, and trans fats in eggs from brown and white egg strains that were molted or nonmolted. Poultry Science 92: 3259-3265.

Association of Official Analytical Chemist's [AOAC]. 2006. Official Methods of AOAC Internacional. AOAC, Rockville, MD, USA.

Edge, R.; McGarvey, D.J.; Truscott, T.G. 1997. The carotenoids as anti-oxidants: a review. Journal of Photochemistry and Photobiology B: Biology 41: 189-200.

Galobart, J.; Sala, R.; Rinco-Arruyo, X.; Manzanilla, E.G.; Vila, B.; Gasa, J. 2004. Egg yolk color as affected by saponification of different natural pigmenting sources. Journal of Applied Poultry Research 13: 328-334.

Hammershøj, M.; Steenfeldt, S. 2012. The effects of kale (Brassica oleracea ssp. acephala), basil (Ocimumbasilicum) and thyme (Thymus vulgaris) as forage material in organic egg production on egg quality. British Poultry Science 53: 245-256.

Harder, M.N.C.; Canniatti-Brazaca, S.G.; Coelho, A.A.D.; Savino, V.J.M.; Franco, C.F. 2007. Cholesterol and iron availability in yolk of laying hens feed wih annatto (Bixa orellana). Animal 1: 477-482.

Horsted, K.; Hammershø, M.; Allesen-Hol, B.H. 2010. Effect of grass-clover forage and whole-wheat feeding on the sensory quality of eggs. Journal of the Science of Food Agriculture 90: 343-348.

Rahimi, J.; Ngadi, M. 2014. Effect of batter formulation and predrying time on oil distribution fractions in fried batter. Food Science and Technology 59: 820-826.
Rizzi, C.; Maragon, A. 2012. Quality of organic eggs of hybrid and Italian breed hens. Poultry Science 91: 2330-2340.

Santos-Bocanegra, E..; Ospina-Osorio, X., Oviedo-Rondon, E.O. 2004 Evaluation of xanthophylls extracted from Tagetes rectus (Marigold Flower) and Capsicum Sp. (Red Pepper Paprika) as a pigment for egg-yolks campare with synthetic pigments. International Journal of Poultry Science11: 685-689.

Scotter, M. 2009. The chemistry and analysis of annatto food colouring: a review. Food Additives \& Contaminants 26:11231145. Sirri, F.; Iaffaldano, N.; Minelli, G.; Melluzzi, A.; Rosatto, M.P.; Franchini, A. 2007. Comparative pigmentation efficiency of high dietary levels of apo-ester and marigold extract on quality traits of whole liquid egg of two strains of laying hens. Journal of Applied Poultry Research 16: 429-437.

Sousa, R.C.S.; Coimbra, J.S.R.; Rojas, E.E.G.; Minim, L.A.; Oliveira, F.C.; Minim, V.P.R. 2007. Effect of $\mathrm{pH}$ and salt concentration on the solubility and density of egg yolk and plasma egg yolk. Food Science and Technology 40: 1253-1258.

Sujatha, T.; Narahari, D. 2010. Effect of designer diets on egg yolk composition of 'White Leghorn' hens. Journal of Food Science and Technology 48: 494-497.

Tallarico, N.; Sirri, F.; Meluzzi, A.; Pittia, P.; Parpinello, G.P.; Franchini, A. 2002. Effect of dietary vegetable lipids on functional and sensory properties of chicken eggs. Italian Journal of Food Science 14: 159-166.

Vyncke, B.W. 1970. Direct determination of the thiobarbituric acid value in trichloracetic acid extracts of fish as a measure of oxidative rancidity. Fette Seifen Anstrichm 72: 1084-1087. 